

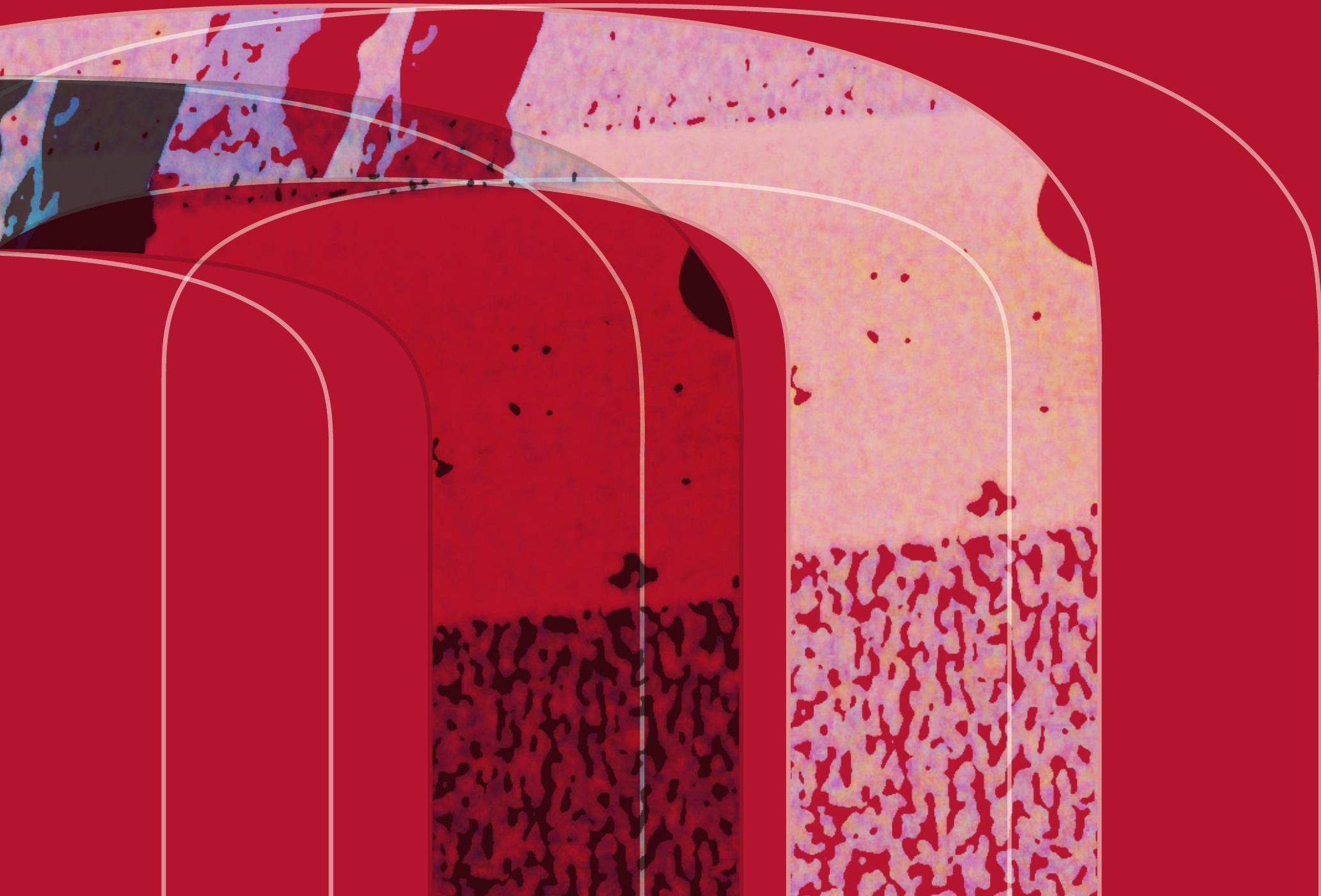




\section{Pohjoismaisen lapsi- ja nuorisoyhteistyön komitean toimintasuunnitelma 2014-2017}

Johdanto

5

Toimintasuunnitelman tarkoitus ja rakenne

7

Pohjoismaisen lapsi- ja nuorisoyhteistyön komitean työ 8

Tehtävä

8

Organisaatio

8

Kohderyhmät

8

Pääpaino lasten ja nuorten syrjäytymisessä

9

Tavoitteet ja panostukset

10

Seuranta ja arviointi 
Pohjoismaisen lapsi- ja nuorisoyhteistyön komitean toimintasuunnitelma 2014-2017

ISBN 978-92-893-3783-0

http://dx.doi.org/10.6027/ANP2014-744

ANP 2014-744

(C) Pohjoismaiden ministerineuvosto 2014

Suunnittelu: Erling Lynder

www.norden.org/fi/julkaisut

Pohjoismaiden ministerineuvosto

Ved Stranden 18

DK-1061 København K

Puhelin (+45) 33960200

www.norden.org

\section{Pohjoismainen yhteistyö}

Pohjoismainen yhteistyö on yksi maailman laajimpia alueellisia yhteistyömuotoja. Yhteistyön piiriin kuuluvat Islanti, Norja, Ruotsi, Suomi ja Tanska sekä Ahvenanmaa, Färsaaret ja Grönlanti.

Pohjoismaista yhteistyötä tehdään politiikan, talouden ja kulttuurin aloilla tärkeänä osana eurooppalaista ja kansainvälistä yhteistyötä. Pohjoismaisen yhteisön tavoitteena on vahva Pohjola vahvassa Euroopassa.

Pohjoismainen yhteistyö pyrkii vahvistamaan pohjoismaisia ja alueellisia etuja ja arvoja globaalissa maailmassa. Maiden yhteiset arvot lujittavat osaltaan Pohjolan asemaa yhtenä maailman innovatiivisimmista ja kilpailukykyisimmistä alueista. 


\section{Johdanto}

\section{"Pohjolan tulee olla maailman paras paikka lapsille ja nuorille."}

Tämä on yleisvisio Pohjoismaiden ministerineuvoston lapsi- ja nuorisoyhteistyön strategiassa, jonka Pohjoismaiden yhteistyöministerit (MRSAM) hyväksyivät vuonna 2009. Strategiassa todetaan, että lapset ja nuoret (0-25 vuotta) ovat Pohjoismaiden ministerineuvoston priorisoima ryhmä ja että Pohjoismaiden ministerineuvoston lapsi- ja nuorisoyhteistyön tavoitteena on edistää lasten ja nuorten mahdollisuuksia hyviin elinolosuhteisiin sekä parantaa heidän vaikutusmahdollisuuksiaan.

Yhteistyöministereillä ja heidän alaisuudessaan toimivalla Pohjoismaisella yhteistyökomitealla (NSK) on päävastuu pohjoismaisesta lapsi- ja nuorisoyhteistyöstä. Työn konkreettisesta sisällöstä vastaavat kuitenkin asianomaiset ministerineuvostot itse. Strategian mukaan ministerineuvostojen tulee sisällyttää lapset ja nuoret omiin toimintoihinsa, analysoida eri päätösten vaikutusta lasten ja nuorten tilanteeseen sekä kehittää mitattavia tavoitteita.

Pohjoismainen lapsi- ja nuorisoyhteistyön komitea (NORDBUK) on Pohjoismaiden ministerineuvoston neuvoa-antava ja koordinoiva elin, joka vastaa pohjoismaisista ja kansainvälisistä lapsija nuorisopoliittisista asioista.
Toimintasuunnitelmassa 2014-2017, joka on järjestyksessä kolmas NORDBUKin toiminnan aikana, painopiste on lasten ja nuorten syrjäytymisessä. Toimintasuunnitelmassa esitellään komitean päämäärät, tavoitteet ja priorisoinnit tulevien neljän vuoden ajalle.

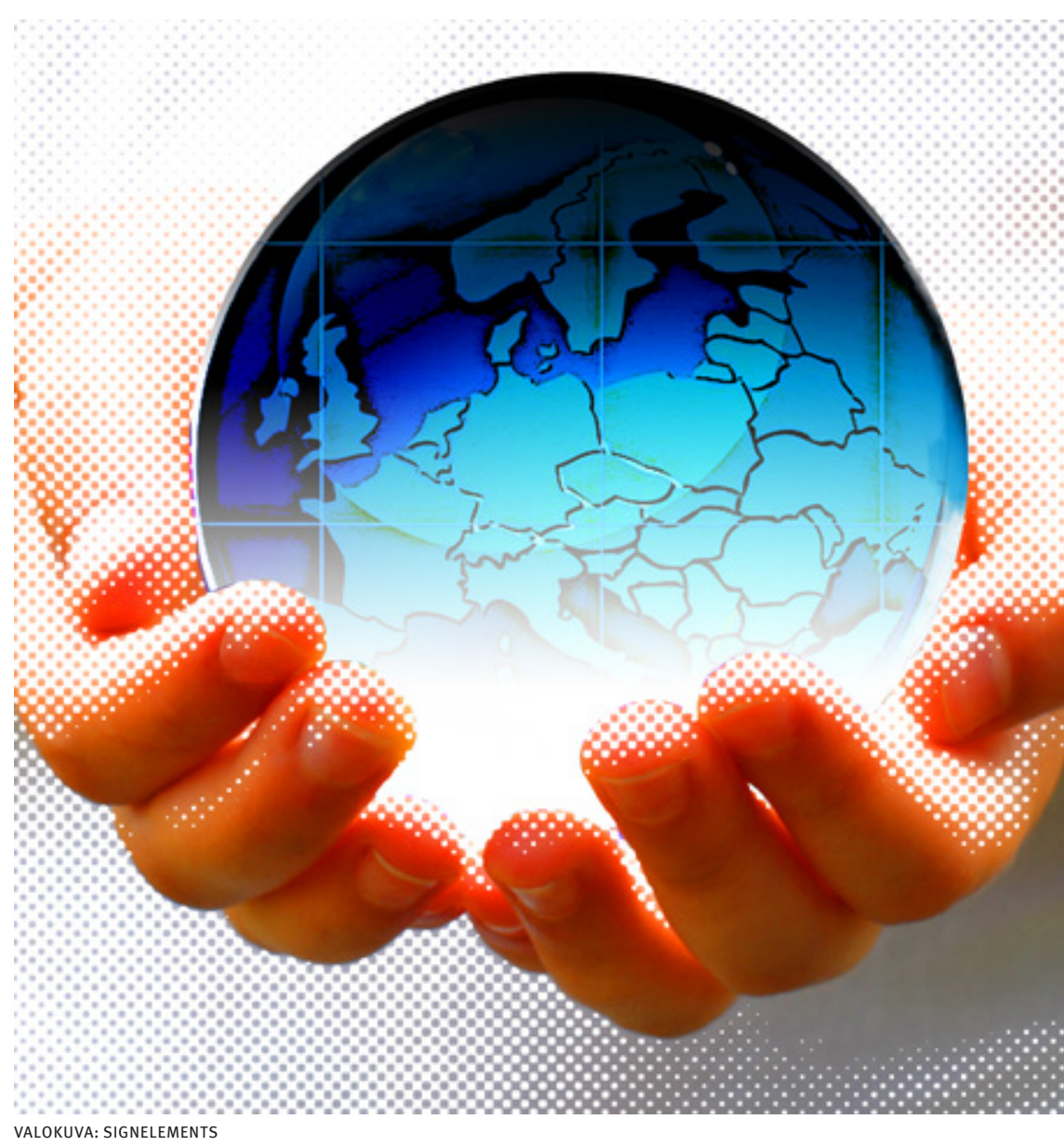





\section{Toimintasuunnitelman tarkoitus ja rakenne}

Toimintasuunnitelman tarkoituksena on priorisoida ja konkretisoida Pohjoismaisen lapsi- ja nuorisoyhteistyön strategian tavoitteita ja visioita. Se luo puitteet myös NORDBUKin vuotuisille toimenpidesuunnitelmille, joista kulloinenkin puheenjohtajamaa vastaa.

Toimintasuunnitelmassa määritellään toiminnan rajaukset, rooli- ja vastuunjako sekä työn tavoitetaso, ja sen tarkoituksena on tukea mahdollisimman hyvin NORDBUKin jatkuvaa toimintaa.
Toimintasuunnitelmassa esitellään aluksi lyhyesti NORDBUKin yleiset tehtävät, organisaatio ja kohderyhmät. Sen jälkeen määritellään komitean yleiset priorisoinnit tulevaksi nelivuotiskaudeksi. Seuraavassa kappaleessa annetaan tarkempi kuvaus kolmesta tavoite- ja panostusalueesta, joihin NORDBUK keskittyy työssään. Lisäksi kunkin tavoite- ja panostusalueen kohdalla mainitaan esimerkkejä toteutettavista toimenpiteistä sekä työtä koskeva rooli- ja vastuunjako. Viimeinen kappale sisältää toiminnan seurantaa ja arviointia koskevat suuntaviivat. 


\section{Pohjoismaisen lapsi- ja nuorisoyhteistyön komitean työ}

\section{Tehtävä}

Kuten Pohjoismaisen lapsi- ja nuorisoyhteistyön strategiassa todetaan, NORDBUK on Pohjoismaiden ministerineuvoston neuvoa-antava ja koordinoiva elin pohjoismaisissa ja kansainvälisissä lapsi- ja nuorisopoliittisissa asioissa. Komitean työ pohjautuu strategiaan ja NORDBUKin tehtävänä on myös koordinoida ja seurata Pohjoismaisen lapsi- ja nuorisoyhteistyön strategiaan liittyvää työtä. Komitea esittää vuosittain yhteistyöministereille yhtenäisen raportin, jossa arvioidaan lapsi- ja nuorisopoliittista työtä ja ehdotetaan muutoksia. Toimintasuunnitelmassa ja puheenjohtajamaan vuotuisissa ohjelmapainotuksissa rajataan ja konkretisoidaan komitean toimintaa.

\section{Organisaatio}

NORDBUKin jäsenet ovat Pohjoismaiden sekä Ahvenanmaan, Färsaarten ja Grönlannin viranomaisten nimeämiä. Myös kansalliset pohjoismaiset nuorisojärjestöt nimeävät jäseniä komiteaan tavoitteena vahvistaa lasten ja nuorten todellista vaikutusvaltaa. Kaikilla jäsenillä on äänioikeus ja päätökset tehdään enemmistöperiaatteella neljän Pohjoismaan ollessa edustettuina. Komitean työtapa määritellään tarkemmin erillisessä Arbetsrutiner för NORDBUK -asiakirjassa.

\section{Kohderyhmät}

NORDBUKin yleistavoite on sama kuin strategia-asiakirjassa vahvistettu visio: Pohjolan tulee olla maailman paras kasvupaikka lapsille ja nuorille. Näin ollen NORDBUKin työn lopullisena kohderyhmänä, johon toteutettavilla toimenpiteillä halutaan vaikuttaa, ovat Pohjoismaiden lapset ja nuoret.

Yleistavoitteeseen pääsemiseksi komitea on määritellyt joukon sisäisiä ja ulkoisia sekä ensisijaisia ja toissijaisia kohderyhmiä työlleen. Sisäisiä kohderyhmiä ovat eri yhteistyöalojen ministerineuvostot, jotka vastaavat lapsi- ja nuorisonäkökulman sisällyttämisestä toimintaansa. Ne muodostavat ensisijaisen kohderyhmän NORDBUKin toiminnassa.

Tärkeimpiä ulkoisia kohderyhmiä ovat kansalliset toimijat, joilla on strateginen vastuu lapsi- ja nuorisopolitiikasta sekä sen täytäntöönpanosta, kuten poliitikot, viranomaiset ja tutkimuslaitokset sekä kansalliset lapsi- ja nuorisojärjestöt. Myös ne ovat ensisijaisia kohderyhmiä NORDBUKin toiminnassa. NORDBUKin ensisijaisten kohderyhmien kautta tavoitettavat toimijat ovat toissijaisia kohderyhmiä. Niitä ovat esimerkiksi kunnat tai muut alueelliset ja paikalliset toimijat, joilla on välitön vastuu lapsija nuorisopoliittisista asioista tai jotka vastaavat lapsi- ja nuorisopoliittisen näkökulman sisällyttämisestä toimintaansa. Toissijaisia kohderyhmiä ovat myös henkilöt ja toimijat, jotka tavoitetaan NORDBUKin rahoituksen avulla toteutettujen hankkeiden ja panostusten kautta. 


\section{Tavoitteet ja panostukset}

Seuraavassa kappaleessa kuvataan tarkemmin kolmea panostusaluetta, joiden parissa NORDBUK työskentelee vuosina 2014-2017. Kaikilla kolmella panostusalueella tehtävä työ kohdistuu erityisesti lasten ja nuorten syrjäytymiseen.

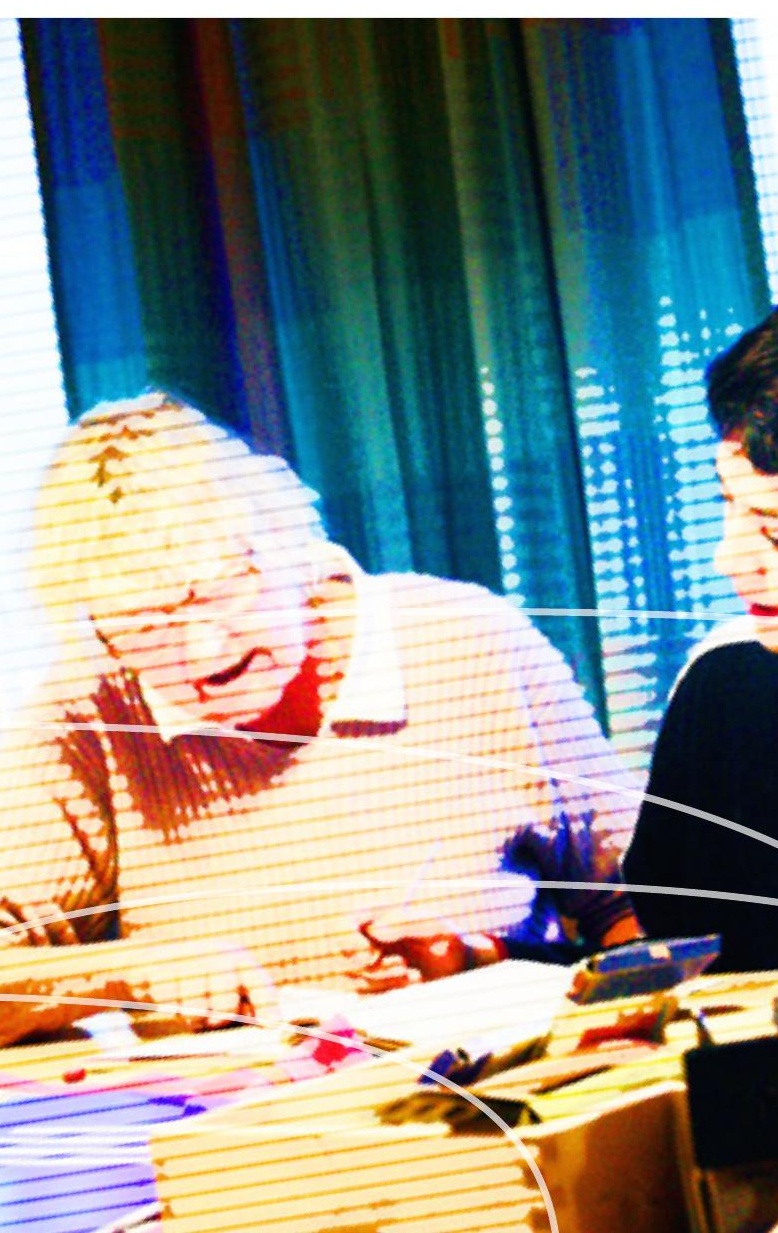

1. Edistetään sektorienvälistä yhteistyötä lapsi- ja nuorisonäkökulman sisällyttäminen pohjoismaiseen yhteistyöhön keskittyen erityisesti lasten ja nuorten syrjäytymiseen.

Tavoite: Vahvistetaan Pohjoismaiden ministerineuvoston edellytyksiä sisällyttää lapsi- ja nuorisonäkökulma toimintaansa.

Panostukset: NORDBUKin tärkeimpiin tehtäviin kuuluu Pohjoismaiden ministerineuvoston eri sektoreiden tukeminen, jotta ne voivat omassa työssään noudattaa Pohjoismaisen lapsi- ja nuorisoyhteistyön strategiaa. NORDBUKin jatkuva toiminta suuntautuu

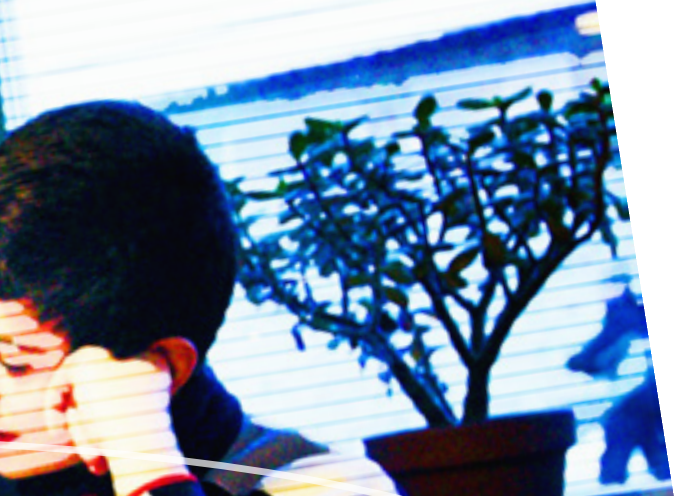


sen vuoksi paljolti Pohjoismaiden ministerineuvoston muiden sektoreiden (eri ministerineuvostojen) tukemiseen ja yhteistyöhön niiden kanssa, jotta ne voivat sisällyttää lapsi- ja nuorisonäkökulman omaan toimintaansa. Työ on luonteeltaan sektorienvälistä. NORDBUK vastaa strategia-asiakirjaan liittyvästä koordinoinnista ja seurannasta ja luovuttaa vuosittain yhteistyöministereille strategian mukaisen yhtenäisen raportin Pohjoismaiden ministerineuvoston työn tuloksista.

\section{Tärkeimmät toimenpiteet:}

- Vuonna 2014 aikana kehitetään työmuodot sektorienväliselle työlle aiempien kokemusten perusteella.

- Vuonna 2015 aikana laaditaan yhteistyössä muiden sektoreiden kanssa tukiaineistoa ja työvälineitä mittareille ja mitattaville tavoitteille eri sektoreita varten.

- Vuonna 2015 kehitetään selkeä prosessi ja konkreettinen tukimalli sektoreiden vuotuiselle raportoinnille lapsi- ja nuorisopoliittisista panostuksista.

- Sektorienvälisen työn tavoitetasoa täsmennetään vuosittain puheenjohtajamaan laatimissa toimenpidesuunnitelmissa.

\section{Seuranta ja arviointi:}

- NORDBUK seuraa vuosittain lapsi- ja nuorisonäkökulman huomioimista Pohjoismaiden ministerineuvoston eri sektoreilla ja luovuttaa vuosiraporttiin sisältyvät päätelmät ja suositukset Pohjoismaiden yhteistyöministereille.
- Pohjoismaiden yhteistyöministereille laaditaan vuonna 2017 perusteellinen analyysi eri yhteistyöalueiden strategiaa koskevista tavoitteista, mittareista ja työstä.

Rooli- ja vastuunjako: NORDBUKin työvaliokunta (AU) laatii ehdotuksen työmuodoiksi sektorienväliselle työlle. Tavoitteena on, että NORDBUK osallistuu vuosittain sektorienvälisten panostusten edistämiseen, suunnitteluun ja toteutukseen. Kukin sektori vastaa itse Pohjoismaisen lapsi- ja nuorisoyhteistyön strategiaa koskevan työn seurannasta omalla yhteistyöalallaan. Pohjoismaiden ministerineuvoston sihteeristö koordinoi seurantajärjestelmänsä yhdessä muiden politiikan alojen kanssa ja yhdenmukaistaa seurantatyötä. NORDBUK laatii vuosittain sihteeristön ja puheenjohtajamaan ehdotuksen pohjalta strategian mukaisen yhtenäisen raportin Pohjoismaiden ministerineuvoston työn tuloksista.

\section{Hankitaan tietoa lasten ja nuorten syrjäytymisestä Pohjoismaissa.}

Tavoite: Laajennetaan tietopohjaa lasten ja nuorten syrjäytymisestä ensisijaisten kohderyhmien parissa Pohjoismaissa, Ahvenanmaalla, Färsaarilla ja Grönlannissa.

Panostukset: NORDBUKin työ suuntautuu olemassa olevan tutkimustiedon, tilastojen sekä Pohjoismaiden lapsiin ja nuoriin liittyvän muun tiedon kokoamiseen ja välittämiseen. Tarkoituksena on helpottaa 
lasten ja nuorten kokemusten sekä heitä koskevan tiedon hyödyntämistä panostusten suunnittelussa, toteutuksessa ja seurannassa Pohjoismaiden ministerineuvostossa.

\section{Tärkeimmät toimenpiteet:}

- NORDBUK laatii tietokoosteita ja levittää tietoa tärkeistä lapsi- ja nuorisonäkökulmista Pohjoismaiden ministerineuvoston eri toiminta-alueille. Työ pohjautuu tähänastisten kokemusten seurantaan ja analysointiin, esimerkiksi tutkimuskoordinaattorilta saatuihin tuloksiin. Lisätietoa on seurantaa ja arviointia koskevassa kohdassa.

- Sektorienvälisen työn puitteissa selvitetään lasten ja nuorten elinoloja ja syrjäytymistä sekä osallistutaan mahdollisuuksien mukaan aihetta koskevaan kokemusten vaihtoon Pohjoismaiden välillä.

- Osallistutaan mahdollisuuksien mukaan kansainvälisiin foorumeihin tavoitteena jakaa Pohjoismaiden kokemuksia ja saada tietoa Pohjoismaille tärkeistä asioista ja haasteista.

\section{Seuranta ja arviointi:}

- Vuonna 2014 laaditaan analyysi siitä, kuinka Pohjoismaiden lapsia ja nuoria koskevaa tietoa voitaisiin paremmin hyödyntää pohjoismaisessa yhteistyössä. Tavoitteena on vahvistaa NORDBUKin roolia osaamisen kehittämisessä. Analyysin toivotaan vastaavan siihen, mitä välineitä tai menetelmiä NORDBUKin tulee käyttää (tutkimuskoordinaattori vai joku muu tapa).
- Strategian seurannan yhteydessä raportoidaan vuosittain siitä, millaista lapsiin ja nuoriin liittyvää uutta tietoa pohjoismaisen yhteistyön avulla on saatu.

Rooli- ja vastuunjako: NORDBUK päättää tiedon kokoamisen ja levittämisen organisoinnista. Todennäköisesti työhön otetaan avuksi ulkoisia toimijoita. Pohjoismaiden ministerineuvoston sihteeristö laatii työhön osallistuvien ulkoisten toimijoiden kanssa tehtävät sopimukset. NORDBUK analysoi yhdessä laaditut tietokoosteet vuosittain ja päättää mahdollisista seurauksista toiminnalle tai uusista priorisoinneista. NORDBUK päättää yhdessä myös mahdollisesta osallistumisesta ja edustuksesta kansainvälisiin lapsi- ja nuorisopoliittisiin foorumeihin.

\section{Edistetään lasten ja nuorten omaa järjestäytymistä, vaikuttamista ja osallistumista demokraattisiin prosesseihin.}

Tavoite: Helpotetaan lasten ja nuorten omaa järjestäytymistä, vaikuttamista ja osallistumista demokraattisiin prosesseihin.

Panostukset: NORDBUKIN työ painottuu lähinnä taloudellisen tuen jakamiseen, jonka tavoitteena on lasten ja nuorten välisen yhteistoiminnan vahvistaminen Pohjoismaissa. Komitea haluaa myös helpottaa lasten ja nuorten vaikuttamista ja osallistumista demokraattisiin prosesseihin. Lisäksi NORDBUKin tehtävänä on edistää kokemusten vaihtoa lapsi- ja 


\section{Seuranta ja arviointi}

NORDBUKin seuranta- ja arviointityön pääpaino on vuotuisessa seurannassa, josta se vastaa Pohjoismaisen lapsi- ja nuorisoyhteistyön strategian mukaisesti. Seurantaan tulee sisältyä selvitys ja arviointi siitä, miten eri ministerineuvostot ovat toteuttaneet strategiaa omassa työssään, ja lisäksi yhteenveto ja analyysi NORDBUKin muusta toiminnasta.

Erityisiä seuranta- ja arviointitoimia on esitelty myös kunkin kolmen panostusalueen kohdalla. Analyysien tarkoituksena on valaista NORDBUKin eri toimenpiteiden vaikutusta niiden ajateltuun rooliin nähden.

Vuonna 2017 arvioidaan lopuksi koko toimintasuunnitelma ennen seuraavan uuden toimintasuunnitelman laatimista NORDBUKille. Arvioinnin tulee sisältää ehdotuksia mahdollisista parannuksista.

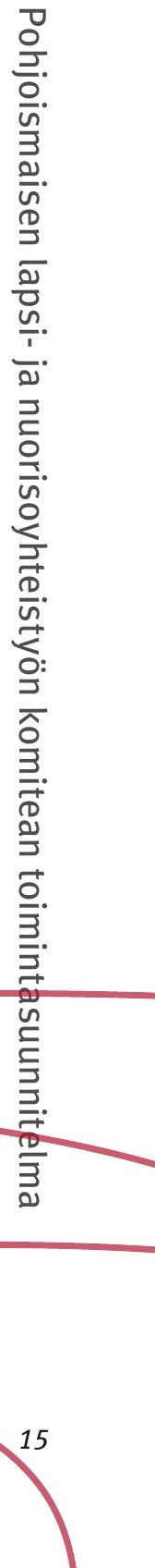




\section{norden}

Pohjoismaiden ministerineuvosto

Ved Stranden 18

DK-1061 København K

www.norden.org

Pohjoismaisen lapsi- ja nuorisoyhteistyön komitean toimintasuunnitelma 2014-2017

"Pohjolan tulee olla maailman paras paikka lapsille ja nuorille."

Tämä on yleisvisio Pohjoismaiden ministerineuvoston lapsija nuorisoyhteistyön strategiassa, jonka Pohjoismaiden yhteistyöministerit (MR-SAM) hyväksyivät vuonna 2009. Strategiassa todetaan, että lapset ja nuoret (0-25 vuotta) ovat Pohjoismaiden ministerineuvoston priorisoima ryhmä ja että Pohjoismaiden ministerineuvoston lapsi- ja nuorisoyhteistyön tavoitteena on edistää lasten ja nuorten mahdollisuuksia hyviin elinolosuhteisiin sekä parantaa heidän vaikutusmahdollisuuksiaan.

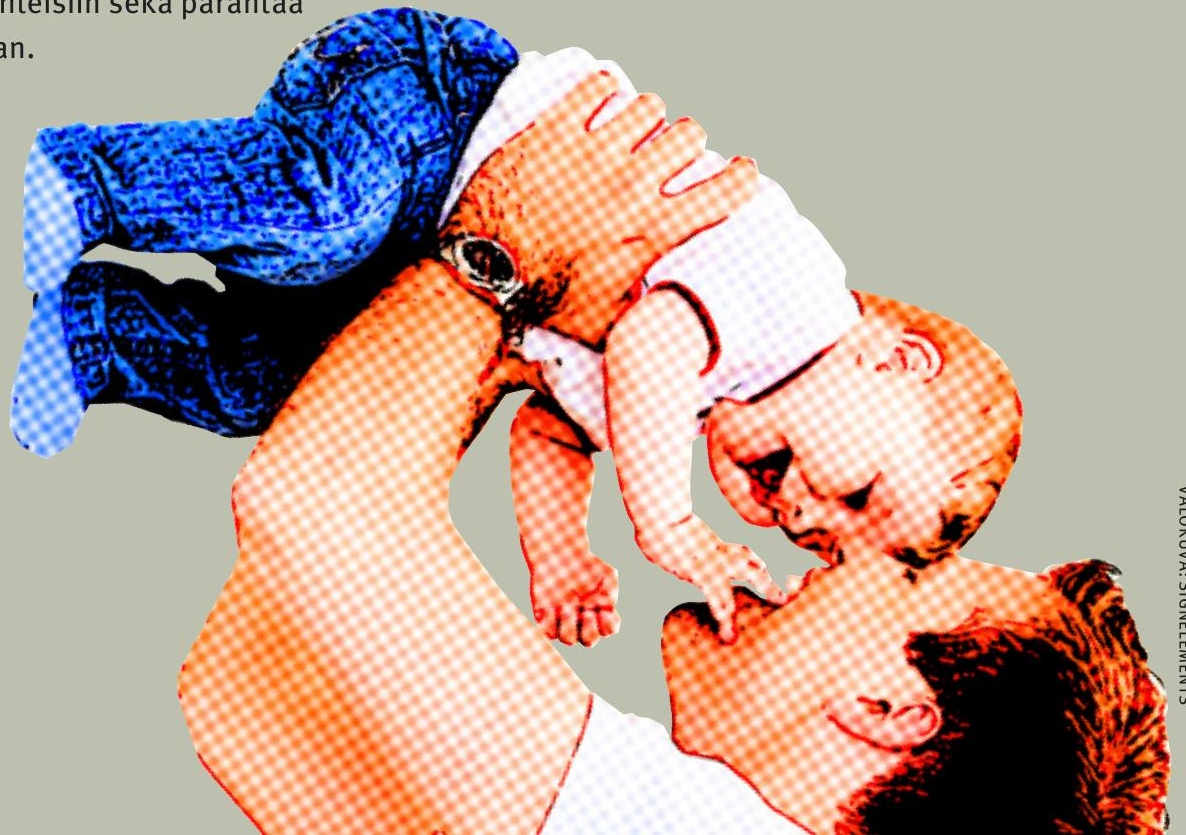

